\title{
Poemas em diálogo
}

Adílson Citelli

Professor livre-docente no Departamento de Comunicações e Artes da ECA-USP

e chefe do Departamento de Comunicações e Artes.

E-mail: citelli@uol.com.br

Na edição n. 3 da revista Comunicação \& Educação - ano XI, set./dez. 2006 -, publicamos o poema No caminho, com Maiakóvski, de Eduardo Alves da Costa, e procuramos aclarar algumas dúvidas acerca da autoria do texto, que ora era atribuído a Maiakóvski, ora a Bertolt Brecht.

Desfeitos os equívocos, trazemos, desta feita, um escrito/poema do teólogo luterano alemão Martin Niemöller (1892-1984), ao que parece escrito em 1933 e que possui fortes vínculos seja com No caminho, com Maiakóvski, seja com alguns poemas do próprio Brecht.

Tais recorrências podem ser pensadas à

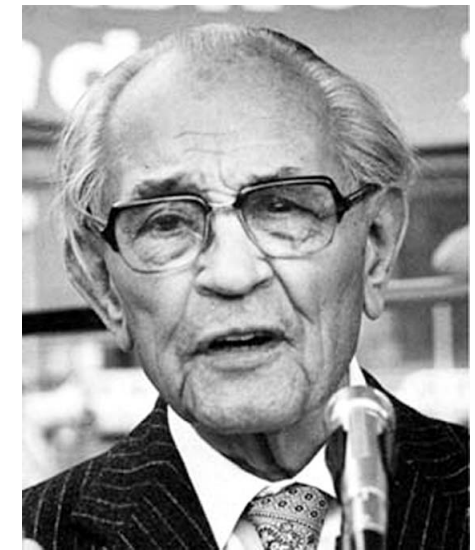

Martin Niemöller, teólogo luterano, vítima do nazismo. luz do conceito de apropriação intertextual, mecanismo que indica como os textos têm a capacidade de promover diálogos entre si, influenciando-se, contaminando-se, dando origem, com isso, a obras que, conquanto mantenham semelhanças, continuam assegurando suas identidades, originalidades, estilos, modos de conceber e dizer as coisas.

A despeito de haver conservado, nos primórdios do nacional-socialismo, algum preconceito anti-semita, Martin Niemöller foi, progressivamente, opondo-se ao ideário nazista, sobretudo a partir da edição do chamado Parágrafo ariano, determinação hitlerista cujo objetivo era segregar os cristãos de origem judaica. Com a finalidade de impedir as mistificações que grupos religiosos alemães aderentes ao nazismo estavam imprimindo à leitura do texto bíblico, Niemöller criou, em 1933, a Liga Pastoral de Emergência, transformada depois na Igreja Engajada

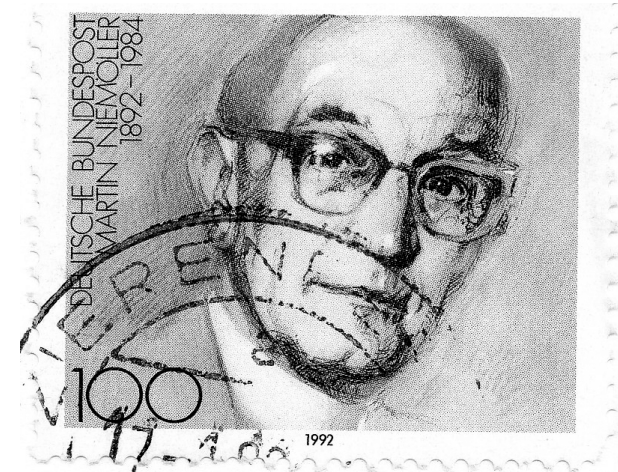

Selo alemão, produzido por Gerd Aretz, em 1992.
- que se voltava contra a direção oficial da Igreja simpática ao Reich.

No bojo dessa luta, o pastor Niemöller virou alvo da Gestapo, sendo detido e libertado algumas vezes, até que, por ordem direta de Hitler, foi encaminhado, em 1938, após processo sumário, primeiro para o campo de concentração de Sachsenhausen e, mais tarde, para Dachau. Permaneceu preso por quase sete anos, até o final da guerra. 
Vejamos a passagem do texto de Niemöller ${ }^{1}$ em alemão e acompanhada de duas traduções.

Zuerst kamen sie für die Kommunisten, und ich war kein Kommunist, und da hab ich nichts gesagt und nichts getan, und dann kamen sie für die Gewerkschaftler, und ich war kein Gewerkschaftler, und sie kamen für die Sozialdemokraten, und sie kamen für die Katholiken, und sie kamen für die Juden, und ich war keiner von denen, und dann kamen sie für mich, und da war keiner mehr, der schreien konnte.
$\mathrm{Na}$ Alemanha, vieram primeiro atrás dos comunistas, e eu nada falei porque não era comunista. Então vieram atrás dos judeus, e eu nada falei porque não era judeu.

Então vieram atrás dos sindicalistas, e eu nada falei porque não era sindicalista.

Então vieram atrás dos católicos, e eu nada falei porque era protestante.

Por fim, vieram atrás de mim e, nessa época, já não havia sobrado ninguém para falar.

Ou em outra possível tradução

Um dia, vieram e levaram meu vizinho que era judeu.

Como não sou judeu, não me incomodei. No dia seguinte, vieram e levaram meu outro vizinho que era comunista.

Como não sou comunista, não me incomodei. No terceiro dia, vieram e levaram meu vizinho católico.

Como não sou católico, não me incomodei. No quarto dia, vieram e me levaram; já não havia mais ninguém para reclamar.
1. <http://www.dhm.de/ lemo/html/biografien/NiemoellerMartin> $[\ldots]$

Na primeira noite eles se aproximam

e roubam uma flor

do nosso jardim.

E não dizemos nada.

Na segunda noite, já não se escondem:

pisam as flores,

matam nosso cão,

e não dizemos nada.

Até que um dia,

o mais frágil deles

entra sozinho em nossa casa,

rouba-nos a luz e,

conhecendo nosso medo,

arranca-nos a voz da garganta.

E já não podemos dizer nada.

[...]. 


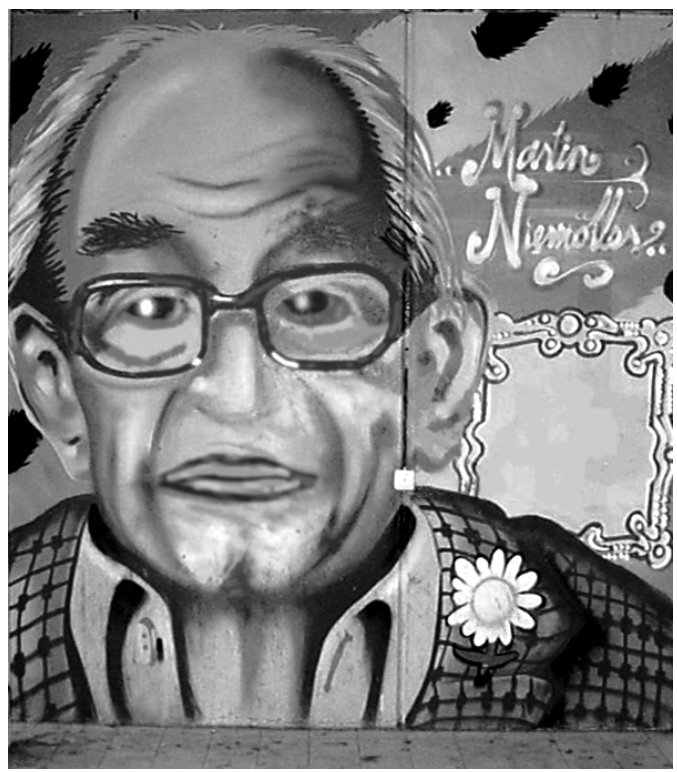

Cartaz do Comitê para Paz, Desarmamento e Cooperação - Martin Niemöller: "Quem deseja a paz, precisa querer viver com o adversário. Precisamos correr o risco da confiança. Por isso, dar um fim ao armamento" (Colônia/Althoff OHG, Parlamento da República Federativa Alemã, 1980, impresso pelo Museu Alemão de História, Berlim - Inv.Nr.: P 96;2762).

Como se percebe, tais semelhanças ou, como dito anteriormente, apropriações intertextuais, que não se confundem com cópia, representam um belo exemplo de como as estruturas discursivas influenciam-se, muitas vezes através de longos e tortuosos caminhos que nem sequer os autores detectam nem possuem domínio ou conhecimento direto.

De todo modo, o texto de Martin Niemöller representa, enquanto tal, um particular exercício poético que mostra, sobretudo, como o absenteísmo político, a conivência com a injustiça, o comodismo individualista podem compor um cenário ideal para o nascimento do "ovo da serpente". 